\title{
FOREWORD
}

\section{Beverage Markets and Policy}

\author{
Harry M. Kaiser, Jill J. McCluskey, \\ and Bradley J. Rickard
}

Beverages are a large component of the total food category and yet the various marketing and policy issues faced by the beverage industry have received relatively little attention among food and agricultural economists. There has been a substantial increase in the variety of beverages available, and this diversity of products provides new opportunities for economists to study consumer demand for specific attributes. At the same time, there is growing concern that some beverages may be important contributors to the rise in obesity in the United States and elsewhere. As a result, various policies have been implemented or are being considered to curb consumption of high-calorie beverages and encourage consumption of healthier beverages. In addition, there has been a proliferation of alcoholic beverage products. Competition by alcoholic products creates an opportunity for agricultural and food economists to study a host of marketing issues that include product labeling and differentiation and the role of geographic proximity (i.e., local foods) on consumer demand. Furthermore, unique policy issues are associated with alcoholic beverages, and many of the policy considerations are complicated because regulations differ widely by state.

The issues related specifically to beverages were examined in a series of papers presented as part of the Northeastern Agricultural and Resource Economics Association (NAREA) workshop "Beverage Markets and Policy," which was held in Ithaca, New York, in June 2013. Based on a peer-review process, we have selected eleven of those papers for this special issue of Agricultural and Resource Economics Review. The principle goal of the NAREA workshop was to convene recognized and emerging experts to debate and advance research on the contemporary economic problems in beverage markets with an emphasis on development of industry-led initiatives and policies that address economic development, sustainable agriculture, and human health considerations.

Each of the articles in this issue falls into one of three broad groups. The first examines consumer response to advertising and public policies in beverage markets and focuses largely on juice and soda products. The second group of articles looks at key marketing considerations in alcoholic beverage markets in selected U.S. regions. Three of the four papers focus on marketing issues in burgeoning wine regions, and the fourth paper examines consumer preferences in the craft beer market. The final group of articles focuses on milk markets and

Harry M. Kaiser is the Gellert Family Professor in the Charles H. Dyson School of Applied Economics and Management at Cornell University, Jill J. McCluskey is a professor in the School of Economic Sciences at Washington State University, and Bradley J. Rickard is an assistant professor in the Charles H. Dyson School of Applied Economics and Management at Cornell University. Correspondence: Bradley Rickard - Dyson School of Applied Economics and Management - Cornell University =137 Reservoir Avenue * Ithaca, NY 14853 - Phone +1.607.255.7417 - Email b.rickard@ cornell.edu. 
policy. Dairy markets and policy issues have received considerable attention by agricultural and food economists in recent years, but this set of papers provides analyses on new topics in this arena.

The first four articles of this special issue examine consumer response to advertising and public policies in beverage markets. Hyeyoung Kim and Lisa House (2014) examine the role of knowledge and perceptions on consumption patterns for several nonalcoholic beverages. Using survey data from a large sample, they show that, for most beverage products studied, consumer perceptions about health have both own-beverage and cross-beverage impacts. Matthew Salois and Amber Reilly (2014) examine the impacts of perceived value and generic advertising efforts in the orange juice market using information from detailed survey data made available by the Florida Department of Citrus. Results here indicate that perceived value does impact consumption and that generic advertising-but not brand advertising-influences the perceived value to consumers. Abigail Okrent and Joanna MacEwan (2014) use Nielsen Homescan data and advertising expenditures to study the effects of advertising and prices on nonalcoholic beverage consumption. They show that the magnitudes of elasticities of demand with respect to advertising are much smaller than their price and expenditure counterparts. Yizao Liu, Rigoberto Lopez, and Chen Zhu (2014) analyze cross-sectional household data from seven urban markets for 2006 through 2008 to assess the possible impacts of a tax on carbonated soft drinks (a price change), elimination of television advertising, elimination of large retail container sizes, and reduction of the sugar content for current products. The authors' econometric results, which are based on two Nielsen data sets, demonstrate that elimination of large retail container sizes would be most effective and taxes on calories would be least effective of the options considered in reducing consumption of carbonated soft drinks.

Four articles focus on a range of marketing issues associated with alcoholic beverage markets. Joe Perla, Brad Rickard, and Todd Schmit (2014) examine demand for local wines by restaurants in New York State using a data set that included information about menus and expert ratings for individual restaurants. Their results show that certain expert ratings and specific cuisine styles are good indicators of the demand for local wine by restaurants. Lin Sun, Miguel Gómez, Fabio Chaddad, and Brent Ross (2014) study the impact of distribution channels on sales for wineries in emerging cool climate regions. Their work demonstrates that the share of wine sold through intermediated market channels increases with a winery's size, age, degree of vertical integration, degree of inter-winery collaboration, intensity of promotion effort, and degree of marketing challenges faced. Jason Franken and Kevin Bacon (2014) examine marketing and procurement decisions by organizations in the burgeoning wine industry in Illinois. Using data from two surveys, the authors find evidence that temporal specificity (related to fruit perishability) increases the probability that formal written contracts will be used by wineries. In addition, both holdup and temporal specificity are shown to increase informal contract use in this industry. Gnel Gabrielyan, Jill McCluskey, Thomas Marsh, and Carolyn Ross (2014) use an economic and sensory experiment to study willingness to pay for craft beers, which are differentiated by product characteristics that include the level of hoppiness. Their work suggests that craft brewers can charge a higher price margin if they brew beers that are differentiated by hoppiness.

The final three articles in this special issue examine dairy markets and dairy policy. Senarath Dharmasena and Oral Capps, Jr. (2014) examine the demand 
for a dairy-alternative functional beverage, soymilk, using Nielsen Homescan data. Using a Tobit econometric model, they find that income, age, employment status, education level, race, ethnicity, region, and presence of children in a household are significant drivers of demand for soymilk. Mélanie Lefèvre (2014) examines preferences of consumers for sour-milk products made with local fresh milk versus ones made with imported powdered milk in the Dakar region of Senegal. Using unique survey data and a hedonic pricing model, the author tests whether there is a price differential for sour milk based on the raw material used to make it and if misinformation (incorrect or deceiving product labeling) is associated with the price for each type of product. The author ultimately finds that misinformation prevents consumers from paying more for products made with local fresh milk. Adam Rabinowitz and Yizao Liu (2014) examine the effect of a change in administration of New York State's controversial milk price gouging law on retail milk prices. Using a regression discontinuity approach, the authors show that the change in the law reduced prices and increased consumer welfare for retail milk purchasers in New York.

As part of the organizing committee for the workshop and as guest co-editors of this special issue, we thank the authors for their participation and cooperation. We also congratulate them for making important contributions to the growing body of research that is examining marketing and policy issues in beverage markets. We hope these papers stimulate additional work by food and agricultural economists who are interested in the wide range of marketing and policy issues that face beverage markets in the United States and elsewhere.

\section{References}

Dharmasena, S., and 0. Capps, Jr. 2014. “Unraveling Demand for Dairy-Alternative Beverages in the United States: The Case of Soymilk." Agricultural and Resource Economics Review 43(1): 140-157.

Franken, J.R.V., and K.J. Bacon. 2014. "Organizational Structure and Operation of the Illinois Wine Industry." Agricultural and Resource Economics Review 43(1): 104-124.

Gabrielyan, G., J.J. McCluskey, T.L. Marsh, and C.F. Ross "Willingness to Pay for Sensory Attributes in Beer." Agricultural and Resource Economics Review 43(1): 125-139.

Kim, H., and L.A. House. 2014. Linking Consumer Health Perceptions to Consumption of Nonalcoholic Beverages." Agricultural and Resource Economics Review 43(1): 1-16.

Lefèvre, M. 2014. "Do Consumers Pay More for What They Value More? The Case of Local Milk-based Dairy Products in Senegal." Agricultural and Resource Economics Review 43(1): 158-177.

Liu, Y., R.A. Lopez, and C. Zhu. 2014. "The Impact of Four Alternative Policies to Decrease Soda Consumption." Agricultural and Resource Economics Review 43(1): 53-68.

Okrent, A.M., and J.P. MacEwan. 2014. "The Effects of Prices, Advertising, Expenditures, and Demographics on Demand for Nonalcoholic Beverages." Agricultural and Resource Economics Review 43(1): 31-52.

Perla, J.M., B.J. Rickard, and T.M. Schmit. 2014. "Looking for Locapours: Using Zagat Survey Data to Examine Restaurant Demand for Local Wine." Agricultural and Resource Economics Review 43(1): 69-86.

Rabinowitz, A.N., and Y. Liu. 2014. "The Impact of Regulatory Change on Retail Pricing: The New York State Milk Price Gouging Law." Agricultural and Resource Economics Review 43(1): 178-192.

Salois, M.J., and A. Reilly. 2014. "Consumer Response to Perceived Value and Generic Advertising." Agricultural and Resource Economics Review 43(1): 17-30.

Sun, L., M.I. Gómez, F.R. Chaddad, and R.B. Ross. 2014. "Distribution Channel Choices of Wineries in Emerging Cool Climate Regions." Agricultural and Resource Economics Review 43(1): 87-103. 